\title{
Migration or photoacclimation to prevent high irradiance and UV-B damage in marine microphytobenthic communities
}

\author{
Jean-Luc Mouget ${ }^{1, *}$, Rupert Perkins $^{2}$, Mireille Consalvey ${ }^{3}$, Sébastien Lefebvre ${ }^{4}$ \\ ${ }^{1}$ Laboratoire de Physiologie et de Biochimie végétales, Faculté des Sciences, Université du Maine, Av. O. Messiaen, \\ 72085 Le Mans Cedex 9, France \\ ${ }^{2}$ School of Earth, Ocean and Planetary Sciences, Cardiff University, Main Building, Park Place, Cardiff CF10 3 YE, UK \\ ${ }^{3}$ National Institute of Water and Atmospheric Research, Private Bag 14-901, Wellington, New Zealand \\ ${ }^{4}$ UMR 100 IFREMER-UCBN, 'Physiologie et écophysiologie des mollusques marins', Laboratoire de Biologie et \\ Biotechnologies Marines, Université de Caen, Esplanade de la paix, 14032 Caen Cedex, France
}

\begin{abstract}
Microphytobenthos (MPB) on intertidal mudflats is a major component of primary producers in some estuarine ecosystems. To sustain photosynthesis, MPB migrate through the upper sediment layer and form transient biofilms during emersion periods, and thus may be exposed to high irradiance and ultraviolet radiation (UV-R), possibly resulting in photodamage to the photosynthetic apparatus. In contrast, downard migration could allow cells to optimize position in the photic zone, avoiding photoinhibitory light levels. Engineered biofilms with inhibited migratory capacity were used to distinguish between possible strategies (photoacclimation or migration) evolved by MPB to cope with photoinhibitory irradiances, when a series of UV filters with different cut-off wavelengths was used to estimate the respective contribution of visible light and UV-R. Engineered biofilms with full migratory capacity maintained a high relative electron transport rate (rETR), in contrast to engineered non-migratory biofilms, which showed a decrease in rETR under high irradiance, with a greater decrease under UV-B radiation. Migration thus appeared to be the principal short-term mechanism allowing MPB to avoid or minimize UV-R and high PAR photodamage in situ. Nevertheless, physiological acclimation processes to different light levels ('light-shade' patterns) seem to occur in the long term, and probably superimpose on migratory capacity, making light history an important component of MPB photoacclimation strategies.
\end{abstract}

KEY WORDS: Microphytobenthos $\cdot$ Migration $\cdot$ Photodamage $\cdot$ Photoinhibition $\cdot$ Ultraviolet radiation

\section{INTRODUCTION}

Estuaries are highly specialized environments and are among the most productive marine ecosystems in the world (e.g. MacIntyre et al. 1996, Underwood \& Kromkamp 1999). In western Europe, the microphytobenthos (MPB) is among the major components of primary producers in estuarine ecosystems. The MPB is composed of prokaryotes (cyanobacteria), and eukaryotes (euglenids and diatoms), with pennate diatoms usually being the dominant group of benthic primary producers (Admiraal 1984). Pennate diatoms are motile, producing extracellular polymeric substances (EPS), to facilitate vertical migration within the upper sediment layer of the tidal flat. MPB migration patterns usually involve upward movement to reach the sediment surface during daytime emersion, and downward movement into the sediment prior to immersion and/or darkness (Consalvey et al. 2004). The bulk of EPS produced, along with the diatom cells and cohesive sediment particles, forms a surface matrix, referred to as a transient biofilm.

Due to a combination of tidal and nycthemeral rhythms along with endogenous rhythms, microphyto- 
benthic algae show complex patterns of vertical migration within sediments, further complicated by variations in light environment and other environmental variables (temperature, salinity, nutrient and water availability, alternation of seasons). Moreover, water currents and meteorological events can disturb biofilm structure and dynamics. MPB photosynthesis is limited to the emersion periods, and daytime emersion can occur once (around midday) or twice a day (morning and afternoon), as a function of tidal and nycthemeral rhythms. MPB can thus be exposed to irradiances up to, and sometimes in excess of, $2000 \mu \mathrm{mol} \mathrm{m} \mathrm{m}^{-2} \mathrm{~s}^{-1}$, when emersion coincides with midday maxima in irradiance (Underwood \& Kromkamp 1999, Perkins et al. 2001). At such high irradiance, planktonic microalgae usually show a decrease in photosynthesis, the extent of which varies according to irradiance level, time or length of exposure, and light history (the accumulated light dose to which the cells have been exposed previously). The decrease in photosynthetic activity caused by high irradiances can be attributed to different phenomena (photoprotection, photoinactivation, photoinhibition, photoacclimation), depending on the time scale considered, the possible existence of photodamage to the components of the photosynthetic apparatus, and their subsequent recovery. Long et al. (1994) considered photoinhibition as 'a light dependent and slowly reversible retardation of photosynthesis,' the consequences of which are a reduction of maximum quantum efficiency for carbon fixation and $\mathrm{O}_{2}$ evolution, and a decrease in photosynthetic rate at saturating light. In a more restrictive definition, photoinhibition corresponds to a failure of photoprotective mechanisms (which mainly refers to change at the photosystem II [PSII] antenna level) to compensate for photoinactivation (which mainly refers to damage at the PSII reaction center level). Detailed definitions of these terms and more information about these phenomena can be found in Franklin et al. (2003) and references therein.

Although a decrease of photosynthesis in MPB has been observed under laboratory conditions and at high photosynthetically active radiation (PAR) (Blanchard et al. 2004, Serôdio 2004, Serôdio et al. 2005, 2006) and elevated ultraviolet-B radiation (UV-B) (Waring et al. 2006), demonstration of the importance of in situ photodamage (caused either by high PAR or UV radiation [UV-R]) in MPB remains a controversial issue (e.g. Blanchard \& Cariou-Le Gal 1994, Sundbäck et al. 1996, Kromkamp et al. 1998, Dodds et al. 1999, Wulff et al. 1999, Waring et al. 2007). Studies on the migration of benthic diatoms have reported speeds of around 2 to $20 \mu \mathrm{m} \mathrm{s}^{-1}$ (Cohn \& Disparti 1994, Consalvey et al. 2004), which is theoretically fast enough to migrate down and leave the mudflat photic zone in a few tens of seconds or at most a few minutes. Hence benthic microalgae may be able to cope with photoinhibitory irradiances through a behavioral mechanism in the form of vertical migration into the sediment and the biofilm where the irradiance is attenuated, thus exposing the MPB to a lower light field. This ability to migrate up and down would reduce the risk of photodamage and maintain the MPB in an optimum light field to maximize photosynthesis overall (e.g. Kromkamp et al. 1998, Perkins et al. 2002), as demonstrated with single-cell fluorescence imaging techniques (Underwood et al. 2005, Waring et al. 2007).

However, MPB biomass and productivity vary on short-term $\left(<\mathrm{d}^{-1}, \mathrm{e} . \mathrm{g}\right.$. Blanchard et al. 1998, Serôdio et al. 2005) and on intermediate time scales $\left(>d^{-1}\right.$, Serôdio \& Catarino 2000, Blanchard et al. 2001, Perkins et al. 2001, Serôdio et al. 2005), and long-term seasonal variations have also been observed (MacIntyre et al. 1996, Barranguet \& Kromkamp 2000, Serôdio \& Catarino 2000). Thus, apart from a behavioral mechanism, i.e. migration into the sediment, to avoid photodamaging irradiances (PAR and UV-R), MPB could also have a physiological mechanism (photoacclimation sensu stricto), resulting in changes in the photosynthetic apparatus, at least over the long term. It is likely that a combination of the 2 processes prevents photoinhibition or photoinactivation in the field, but controversy remains about their relative importance in the short term. Illustrating a temporal dependence to estimate the importance of possible damage, it has been recently demonstrated that in the short term, migration capacity allows benthic microalgae to prevent accumulation of UV-B induced damages, but in the longer term, carbon uptake and allocation can be altered by UV-B (Waring et al. 2007).

In this study, engineered biofilms with inhibited migratory capacity were used to evaluate the importance over the short term of an MPB behavioral strategy (migration) potentially evolved to minimize the effect of photoinhibitory irradiances (PAR and UV-R). Thus the first aim of our work was to study the response of MPB to natural PAR and UV-R in the field, assessing the respective importance of migration and physiology. Our second aim was to estimate the intrinsic importance of natural PAR, UV-A, and UV-B irradiances in the possible photoinhibition of engineered biofilms, in relation to their migratory capacity and photoacclimation status, using a series of UV filters with different cut-off wavelengths.

\section{MATERIALS AND METHODS}

Two series of experiments were carried out in July and September 2003 at the Baie des Veys, on the east 
coast of Cotentin, France $\left(49^{\circ} 22^{\prime} \mathrm{N}, 1^{\circ} 07^{\prime} \mathrm{W}\right)$. Two other series were run in 2004: one in April at St Andrews, Scotland $\left(56^{\circ} 22^{\prime} \mathrm{N}, 02^{\circ} 51^{\prime} \mathrm{W}\right)$, and one in June in Le Mans, France $\left(48^{\circ} 01^{\prime} \mathrm{N}, 00^{\circ} 09^{\prime} \mathrm{E}\right)$. This provided a range of ambient irradiance conditions (PAR and UV irradiances, Table 1), as during the respective emersion periods (between 10:00 and 15:00 h local time), there were clear and sunny sky conditions in Baie des Veys (8 July and 14 September 2003) and in Le Mans (8 June 2004), and cloudy conditions in St Andrews (8 April 2004).

Light treatments. Three light conditions were compared: ambient light (no filter over the biofilms), hereafter referred to as 'UV-B + UV-A' treatment; ambient light without UV-B (biofilms covered with Schott WG 320 long-pass filters, which eliminate UV-B), hereafter 'UV-A' treatment; and ambient light without UV-R (biofilms covered with Schott GG 400 long-pass filters, which eliminate all UV-R), hereafter 'No UV' treatment. Transmittance spectra of the UV Schott filters are given in Fig. 1. Incident visible irradiance as photosynthetically active photon flux density (PPFD, $\mu$ mol photons $\mathrm{m}^{-2} \mathrm{~s}^{-1}$ ) was measured with a Li-Cor quantum meter Li-189 (quantum sensor Q21284). UV irradiance was measured with an HD 9021 UV radiometer (DeltaOhm) equipped with an LP 9021 UVA and an LP 9021 UVB sensor. Light treatments were applied during tidal emersion (see below), and pulse-amplitude-modulated (PAM) fluorescence was used to obtain rapid light-response curves (RLCs) of relative electron transport rate (rETR) versus actinic irradiance $(E)$ as described below.

Experimental setup for in situ migratory biofilms. Preliminary measurements were made on 8 July 2003 at Baie des Veys. The Schott filters were placed $1 \mathrm{~cm}$ above the mudflat surface immediately at the start of the emersion period during spring tide (at 10:00 $\mathrm{h}$ local time), prior to biofilm formation at the surface. Controls consisted of defined areas not covered by a filter, but

Table 1. Irradiances measured on experimental days at the beginning and at the end of the experiments, approximately corresponding to the middle and the end of the emersion periods (ca. 10:00 to 15:00 h). PAR: photosynthetically active radiation. UV-B/UV-A: UV-B to UV-A ratio

\begin{tabular}{|lcccc|}
\hline & $\begin{array}{c}\text { PAR } \\
(\mu \mathrm{mol} \text { photons } \\
\left.\mathrm{m}^{-2} \mathrm{~s}^{-1}\right)\end{array}$ & $\begin{array}{c}\mathrm{UV}-\mathrm{A} \\
\left(\mathrm{W} \mathrm{m}^{-2}\right)\end{array}$ & $\begin{array}{c}\mathrm{UV}-\mathrm{B} \\
\left(\mathrm{W} \mathrm{m}^{-2}\right)\end{array}$ & $\begin{array}{c}\text { UV-B/UV-A } \\
(\%)\end{array}$ \\
\hline Baie des Veys & & & & \\
$\quad$ 8 July 2003 & $1740-1860$ & $12.8-19.1$ & $0.88-1.03$ & $6.9-5.4$ \\
$\quad$ 14 September 2003 & $2060-2050$ & $24.2-26.4$ & $1.63-1.55$ & $6.7-5.9$ \\
$\begin{array}{l}\text { St Andrews } \\
\text { 8 April 2004 } \\
\text { Le Mans } \\
\text { 8 June 2004 }\end{array}$ & $409-535$ & $3.4-5.3$ & $0.16-0.24$ & $4.7-4.5$ \\
\hline
\end{tabular}

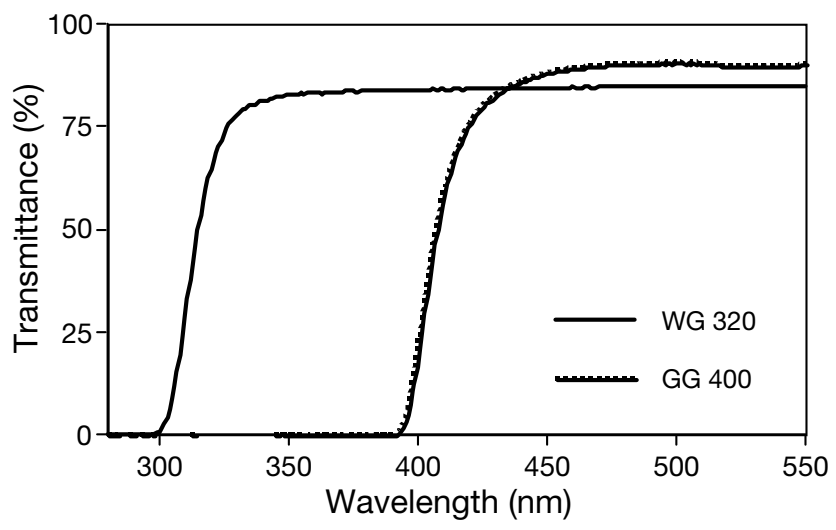

Fig. 1. Transmittance of long-pass filters used for the light treatments: control ('No UV,' Schott GG 400), no UV-B ('UV$A_{1}^{\prime}$ Schott WG 320). The treatment 'UV-B + UV-A' was achieved by the absence of filters over the sediment surface (see Fig. 2)

with an empty filter holder, adjacent to the Schott filters. Filters and controls were arranged in a random block design over an area of approximately $1 \mathrm{~m}^{2}$ chosen due to the visual uniformity of the biofilm density as observed by inspection during the previous emersion periods. The biofilm was composed of Craticula cuspidata (dominant species), Lyrella sp., Pinularia sp., and Navicula transitrans. RLCs (described in 'Photosynthetic measurements' below; Ralph \& Gademann 2005, Perkins et al. 2006) were obtained on the developing natural biofilms, in the middle $(12: 00 \mathrm{~h})$ and at the end $(15: 00 \mathrm{~h})$ of the emersion period.

Experimental setup for engineered biofilms. Experiments using engineered biofilms were run on 14 September 2003 in Baie des Veys, on 8 April 2004 in St Andrews, and on 8 June 2004 in Le Mans. Unless specified, the day before the experiments, several liters of surface (up to $1 \mathrm{~cm}$ approximate depth) sediment were collected, and then autoclaved in the laboratory. The natural microalgal assemblage of motile cells was collected nearby on the mudflat using the lens tissue method (Eaton \& Moss 1966), re-suspended in seawater, and left to settle overnight at room temperature. The biofilms were dominated by diatoms of the genera Pleurosigma and Navicula (Baie des Veys, 2003), Pleurosigma angulatum, Gyrosigma sp., Nitzschia spp., and Navicula spp. (St Andrews, 2004), and the genera Navicula, Pleurosigma, and Nitzschia (Le Mans, 2004). The sterilized mud was poured in a series of Baby Sterilin Petri dishes (ca. $1 \mathrm{~cm}$ depth), and covered with a layer of lens tissue (Fig. 2). Another series of Petri dishes only 


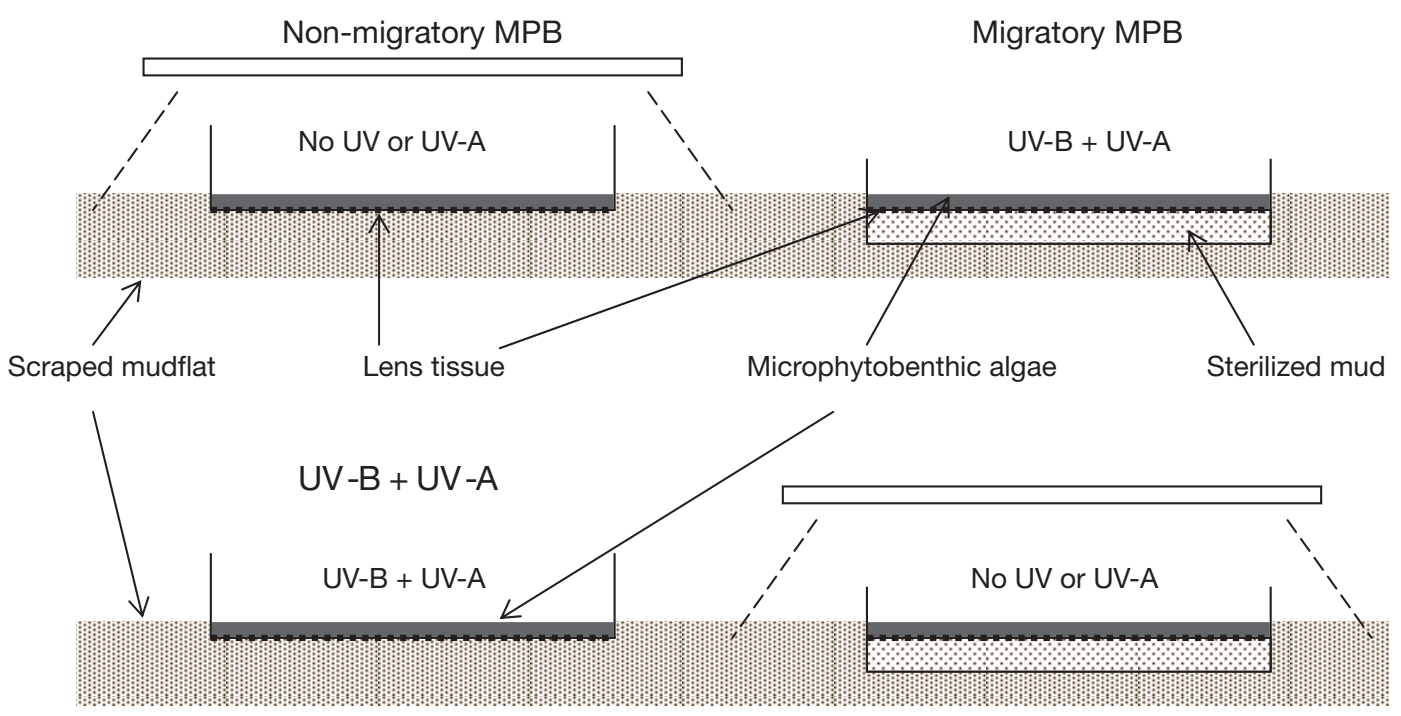

Fig. 2. Set-up for migratory and non-migratory experiments. Engineered biofilms were made by laying down a thin layer of microphytobenthic algal suspension on lens tissue. For migratory engineered biofilms, the lens tissue covered sterilized mud poured into Petri dishes; for non-migratory engineered biofilms, the lens tissue covered the bottom of the Petri dishes. MPB: microphytobenthos

received a disc of lens tissue. The algae collected as described above were concentrated by filtration through fine muslin (pore size $\sim 10 \mu \mathrm{m}$ ) and re-suspended in filtered seawater from the same site. This concentrated culture was homogenized by gentle mixing prior to being aliquoted into the Petri dishes containing either the sterilized mud and a layer of lens tissue (migratory biofilms), or a layer of lens tissue alone (non-migratory biofilms) described above. The Petri dishes were placed on the mudflat in situ after scraping the first $\mathrm{cm}$ of mud away so as to remove extra biomass, resulting in a uniform temperature in each treatment. For the $1 \mathrm{~h}$ incubation, samples were kept from drying by adding a few drops of seawater on demand. In June 2004, due to coastal overcast conditions, experiments were carried out in Le Mans to achieve high light exposure. MPB and mud were sampled on a mudflat near Ouistreham $\left(49^{\circ} 16^{\prime} \mathrm{N}, 00^{\circ} 15^{\prime} \mathrm{W}\right)$ on 5 June, and transported to the Le Mans ex situ experimental site. To ensure a change of photoacclimation state, MPB were stored for $3 \mathrm{~d}$ in $500 \mathrm{ml}$ Erlenmeyer flasks, placed at room temperature and in low light $\left(<100 \mu \mathrm{mol} \mathrm{m}^{-2} \mathrm{~s}^{-1} \mathrm{PAR}\right)$, stirred once a day, and the seawater was changed daily. An artificial mudflat was created using a ca. $1 \times 1 \mathrm{~m}$ tray containing sterilized mud to a depth of $5 \mathrm{~cm}$. Experiments were run in triplicate, between the middle $(12: 00 \mathrm{~h})$ and the end $(14: 00 \mathrm{~h})$ of the emersion period, with RLCs obtained at the end of each treatment period.

Photosynthetic measurements. PAM fluorescence (DIVING PAM fluorometer, Walz) was used to determine photosynthetic activity (as rETR) versus actinic irradiance $(E)$ in the form of RLCs. The tip of the optical fiber was mounted inside a custom-made darkadaptation chamber, so that it was placed $5 \mathrm{~mm}$ above the biofilm surface. Prior to all sets of RLCs, the DIVING-PAM auto-zero function was set using sterilized mud, and light calibration was checked at intervals of every 3 RLCs, using the Diving-PAM quantum meter, corrected against a calibrated Li-Cor LI-189 quantum meter (Perkins et al. 2006). Biofilms were dark-adapted for 5 min before running the RLCs, generated using pre-selected incremental sequences of 8 actinic light levels. During the RLC measurement, biofilms were exposed to $30 \mathrm{~s}$ of irradiance at each incremental step. The saturating pulse (600 ms at intensity setting 10) was optimized before each series of experiments, resulting in a rise to the maximal fluorescence yield of the light-adapted sample $\left(F_{\mathrm{m}}{ }^{\prime}\right)$. The effective quantum efficiency of electron transport through PSII was determined according to the formula $\Phi_{\mathrm{PSII}}=\left(F_{\mathrm{m}}{ }^{\prime}-F^{\prime}\right) / F_{\mathrm{m}}{ }^{\prime}$ (Genty et al. 1989), where $F^{\prime}$ is the operational fluorescence yield at each light level. It should be noted that during RLCs, $F^{\prime}$ does not reach steady-state, and thus RLCs are a compromise measurement used in situ to minimize errors induced by migration and artifacts induced by the experimental method (e.g. Perkins et al. 2006, Herlory et al. 2007). Following Schreiber et al. (1994), the rETR is then given by $\mathrm{rETR}=\Phi_{\mathrm{PSII}} \times E \times 0.5$, where $E$ is the actinic irradiance ( $\mu \mathrm{mol}$ photons $\mathrm{m}^{-2}$ $\mathrm{s}^{-1}$ ). The electron transport rate is expressed in relative units, since the fraction of light absorbed by PSII $\left(a^{*}\right)$ is problematical for measuring intact biofilms (Morris et al. 2008). 
Statistical analysis. The photosynthetic parameters (the maximum light utilization coefficient $[\alpha]$, maximum rETR $\left[\mathrm{rETR}_{\max }\right]$, and light saturation parameter $\left.\left[E_{k}\right]\right)$ were determined by fitting photosynthesis versus irradiance curves (rETR-E curves), using the model of Eilers \& Peeters (1988):

$$
\mathrm{rETR}=E /\left(\mathrm{a} E^{2}+\mathrm{b} E+\mathrm{c}\right)
$$

where $\mathrm{a}, \mathrm{b}$, and $\mathrm{c}$ are adjustment parameters and $\alpha=$ $1 / \mathrm{c}, \mathrm{rETR}_{\max }=1 /(\mathrm{b}+2 \sqrt{\mathrm{ac}}), E_{\mathrm{k}}=\mathrm{c} /(\mathrm{b}+2 \sqrt{\mathrm{ac}})$.

Curve fitting was achieved using the downhill simplex method of the Nelder-Mead model, and standard errors of parameters were estimated by a bootstrap method under Fortan 77 code (Press et al. 2003). All fittings were tested by analyses of variance $(p<0.001)$, residuals being tested for normality and homogeneity of variance, and the significance of parameters tested by Student's $t$-test $(\mathrm{p}<0.05)$. If a model parameter was not significantly different from 0 (e.g. if no photoinhibition occurred), it was removed from the equation, and the model was fitted again with the remaining parameters. Comparisons between RLCs were achieved by testing differences between parameters $(a, b, c)$ of the model of Eilers \& Peeters (1988), and RLC parameters $\left(\alpha, \mathrm{rETR}_{\max }, E_{k}\right)$, as a function of light treatment (No UV, UV-A, UV-B + UV-A) or migration capacity (migratory versus non-migratory), using the method of Ratkowski (1983) for non-linear models.

\section{RESULTS}

\section{Natural migratory biofilms}

A preliminary series of experiments was run on natural biofilms formed at the sediment surface, thus displaying vertical migration. All RLCs (rETR versus irradiance) measured in situ on these natural biofilms showed little saturation, irrespective of the light treatment or the time of the emersion period, and no pattern of photoinhibition was observed (data not shown). Values of $\mathrm{rETR}_{\max }$ calculated by the mathematical model of Eilers \& Peeters (1988) were the highest at the end of the emersion period, but no significant difference could be observed between light regimes, with the exception of the UV-B + UV-A treatment (no filter over the mud), which was significantly lower at the middle of the emersion period (not shown). Differences between parameters of the mathematical model of Eilers \& Peeters (1988) and of photosynthetic parameters for the fitted curves were not significant. In particular, no difference was observed in the values of parameter $\mathrm{c}$, and as a consequence, in the maximum light use efficiency $(\alpha)$, again irrespective of the treatment or the time of the emersion period.

\section{Engineered biofilms}

The role of migration as a means to minimize the effects of photoinhibitory irradiance was studied using migratory and non-migratory engineered biofilms. In the experiments run in Baie des Veys (September 2003), after $1 \mathrm{~h}$ exposure to the different light treatments, engineered biofilms exhibited significantly $(\mathrm{p}<$ 0.05) different photosynthetic parameters, depending on their migratory capacity. Migratory biofilms showed higher rETR, no photoinhibitory pattern, and no effect of UV-A or UV-B radiation compared to the control (No UV treatment; Fig. 3A). Non-migratory biofilms showed a significant depression of rETR $_{\max }$ for all treatments $(p<0.05)$, when compared to migratory biofilms exposed to the corresponding light regime, with a significantly higher decrease in the presence of UV-B (UV-B + UV-A treatment; Fig. 3B). The decrease in $\mathrm{rETR}_{\max }$ reached a factor of ca. 4 for No UV and UVA treatments and ca. 7 for the UV-B + UV-A treatment (Fig. 4A). The intial slope $\alpha$ of the RLCs was signifi-

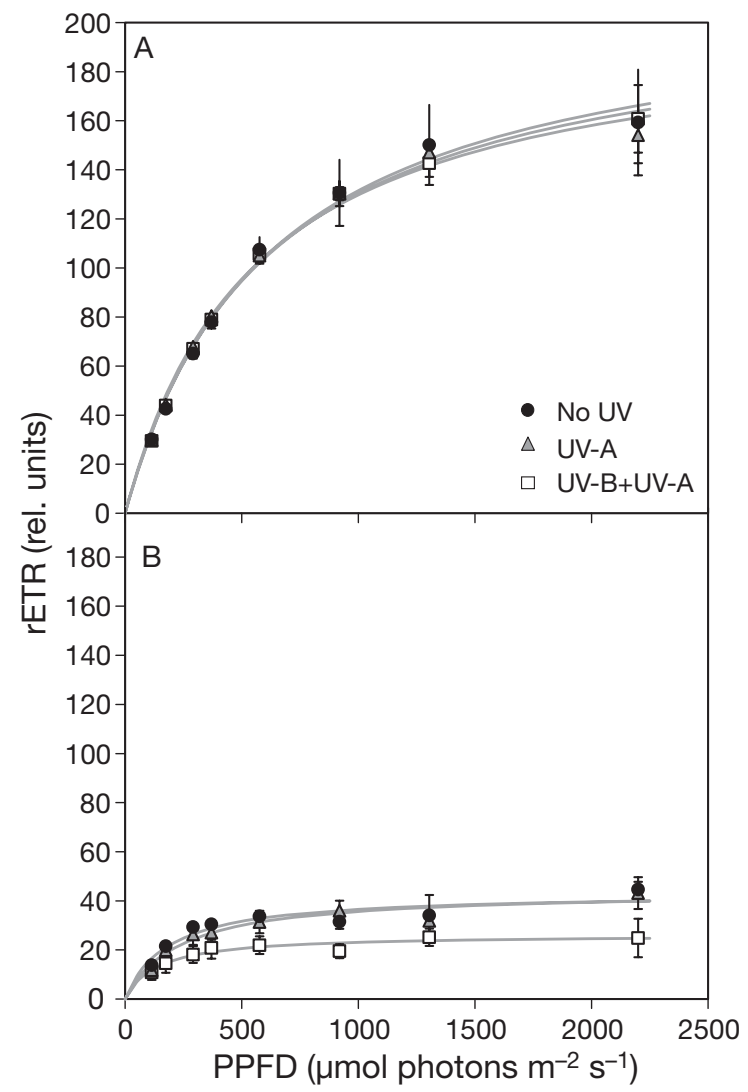

Fig. 3. Rapid light-response curves (RLCs) for (A) migratory and (B) non-migratory engineered biofilms (Baie des Veys, 14 September 2003) exposed for $1 \mathrm{~h}$ to ambient light (UV-B + UV-A), ambient light without UV-B (UV-A), and ambient light without UV radiation (No UV). rETR: relative electron transport rate; PPFD: photosynthetically active photon flux density 


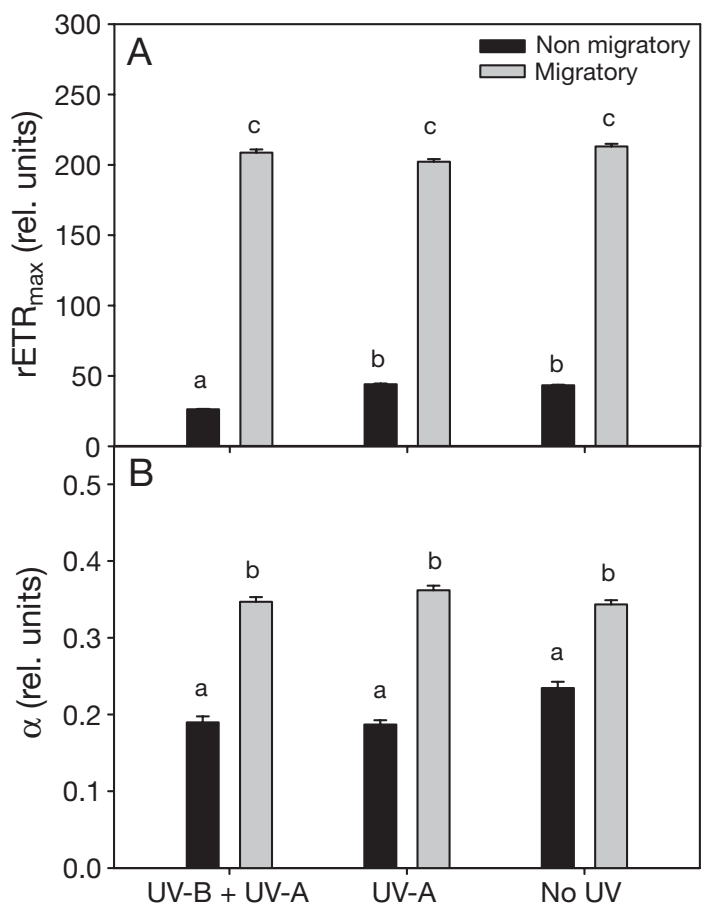

Fig. 4. RLC parameters for light curves obtained on migratory and non-migratory biofilms (Baie des Veys, 14 September 2003) exposed for $1 \mathrm{~h}$ to ambient light (UV-B + UV-A), ambient light without UV-B (UV-A), and ambient light without UV radiations (No UV), as shown in Fig. 3. (A) Maximum ETR $\left(\mathrm{rETR}_{\max }\right),(\mathrm{B})$ maximum light use coefficient $(\alpha)$

cantly higher in migratory biofilms (Fig. 4B). The saturation parameter $E_{k}$ showed a pattern similar to $\alpha$, with the exception of non-migratory biofilms without UV-B (UV-A treatment; not shown).

The experiment was repeated in St Andrews in April 2004, with a different biomass and lower PAR and UV irradiances (see Table 1). For both engineered biofilms (Fig. 5, 'migratory' and 'non-migratory,' respectively), no significant difference was observed between treatments for all RLC parameters. Furthermore, the light curves showed a decline in rETR at irradiances higher than $E_{k}$, indicative of low-light acclimation. This last result and the lack of a specific effect of natural UV-R were confirmed the following day, using only engineered non-migratory biofilms because the remaining MPB biomass was insufficient (data not shown).

\section{Artificial change of MPB photoacclimation state}

A new set of experiments to compare 'migratory' and 'non-migratory' engineered biofilms was run in Le Mans (June 2004) under irradiance conditions similar to those observed in Baie des Veys in September 2003 (Table 1), but with MPB acclimated to low light for $3 \mathrm{~d}$. On 8 June, after $1 \mathrm{~h}$ of exposure to the different light

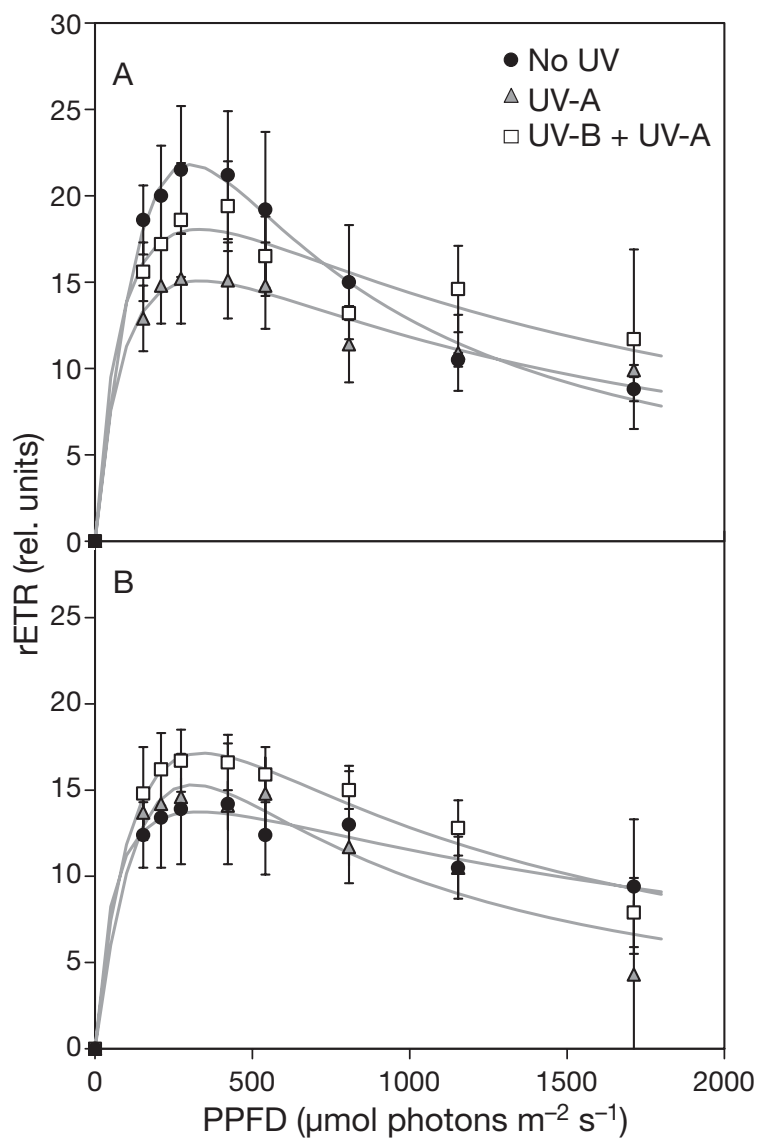

Fig. 5. RLCs for migratory (A) and non-migratory (B) engineered biofilms (St Andrews, 8 April 2004) exposed for $1 \mathrm{~h}$ to ambient light (UV-B + UV-A), ambient light without UV-B (UV-A), and ambient light without UV radiation (No UV)

treatments, migratory biofilms had almost completely disappeared from the mud surface (change in surface coloration), and the non-migratory biofilms were completely photoinhibited, resulting in both cases in extremely weak fluorescence yields (data not shown). The remaining biomass was not sufficient to run a complete series of experiments. Thus, the development of photoinhibition over time was first followed on non-migratory engineered biofilms exposed to PAR only (No-UV treatment) from 5 to $20 \mathrm{~min}$ (no replicates). The evolution of RLC parameters over time showed a decrease of $\mathrm{rETR}_{\max }$, with the highest decrease during the first 5 to $10 \mathrm{~min}$ of exposure to photoinhibitory PAR irradiance, and all light curves were typical of low-light-acclimated algae (Fig. 6). Given this time-dependent decrease in photosynthetic response, a last series of experiments was run to compare non-migratory engineered biofilms exposed for 5 and $10 \mathrm{~min}$ to the different light treatments (No UV, UV-A, UV-B + UV-A). All RLCs confirmed the low-light-acclimated pattern, with rETR decreasing at high irradi- 


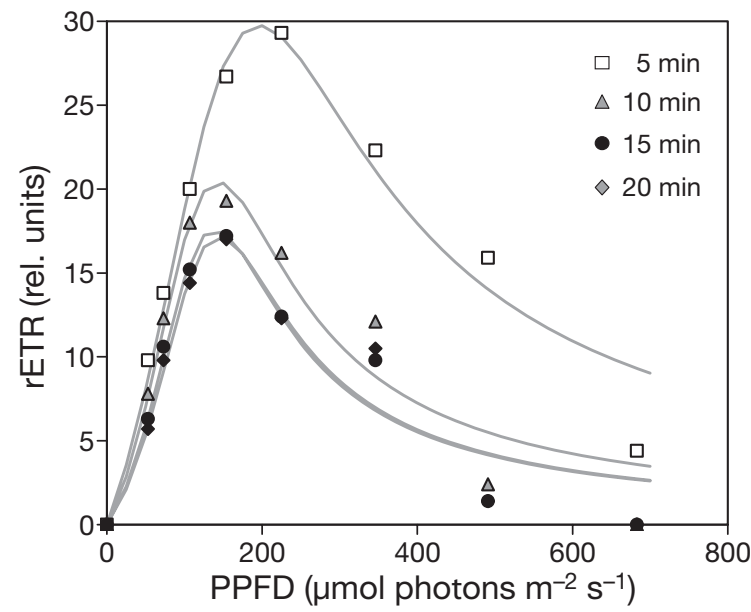

Fig. 6. Development of photoinhibition over time in nonmigratory engineered biofilm (Le Mans, 8 June 2004). RLCs were obtained after $5,10,15$, or 20 min exposure to ambient light without UV radiation (No UV)

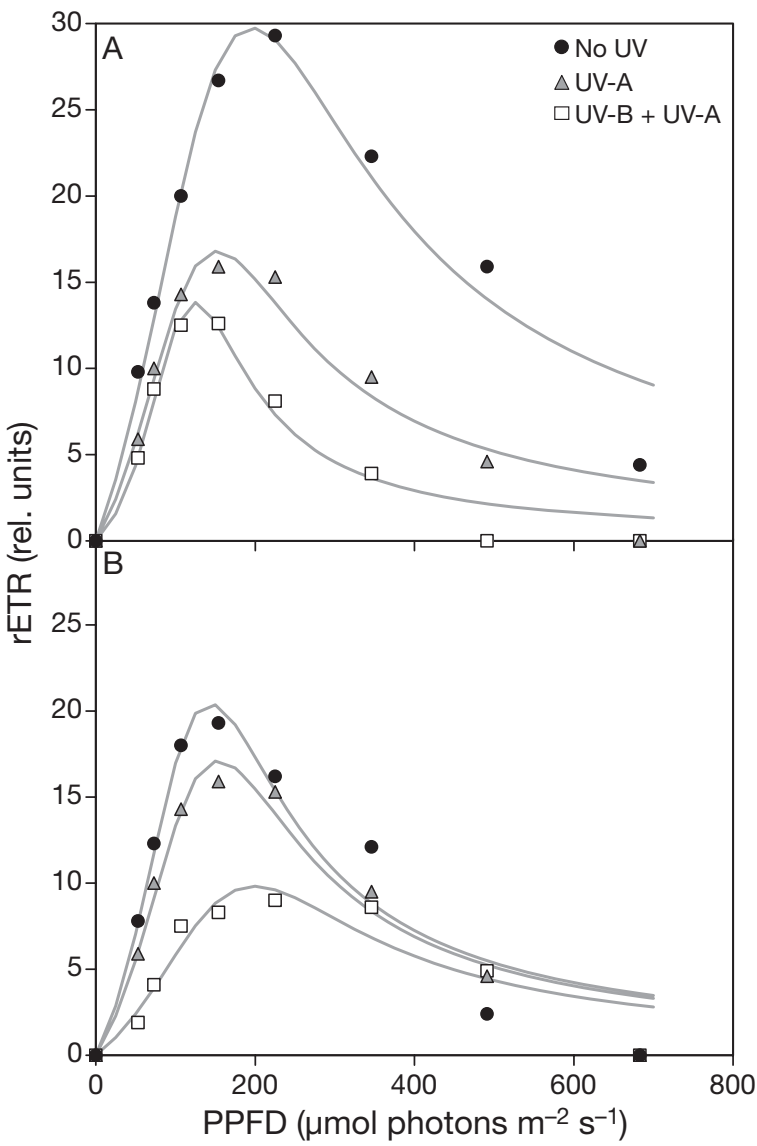

Fig 7. RLCs for non-migratory engineered biofilms (Le Mans, 8 June 2004) exposed for (A) 5 or (B) 10 min to ambient light (UV-B + UV-A), ambient light without UV-B (UV-A), and ambient light without UV radiation (No UV)

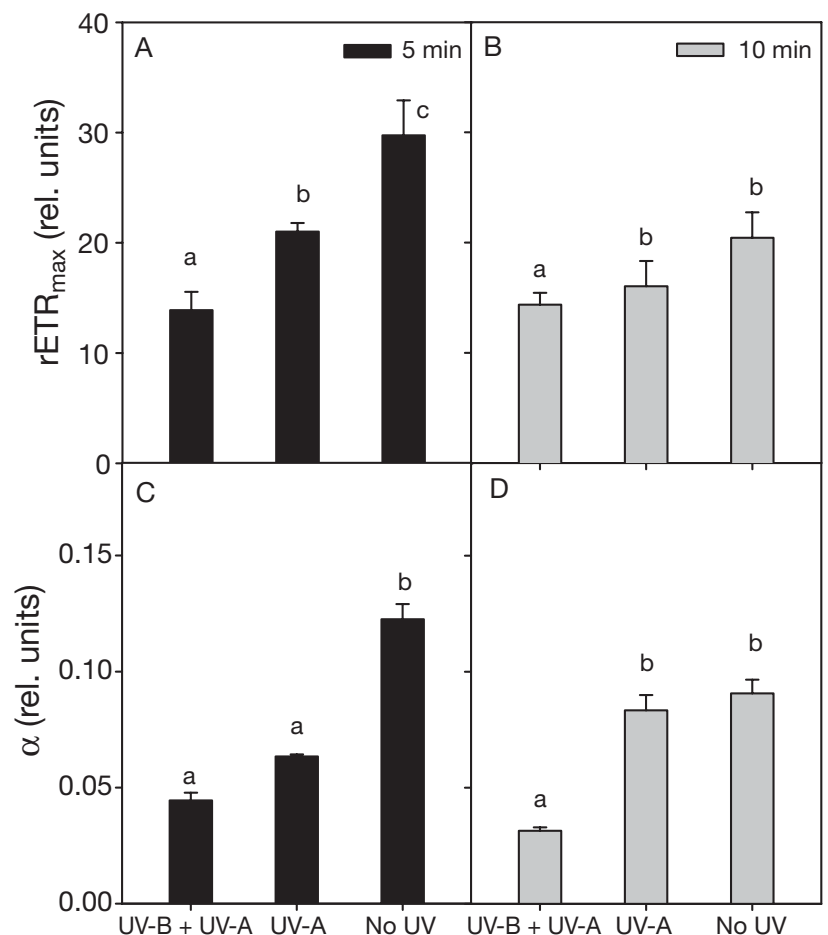

Fig. 8. RLC parameters for light curves obtained on nonmigratory engineered biofilms (Le Mans, 8 June 2004) exposed for $(\mathrm{A}, \mathrm{C}) 5$ or $(\mathrm{B}, \mathrm{D}) 10 \mathrm{~min}$ to ambient light (UV-B + UV-A), ambient light without UV-B (UV-A), and ambient light without UV radiation (No UV), as shown in Fig. 7. (A,B) Maximum ETR $\left(\mathrm{rETR}_{\max }\right),(\mathrm{C}, \mathrm{D})$ maximum light use coefficient $(\alpha)$

ances (Fig. 7). Compared to the control ('No UV'), UV$\mathrm{R}$ decreased photosynthetic activity, with the greatest decrease under the UV-B + UV-A treatment (Fig. 8).

\section{DISCUSSION}

It is generally accepted that 3 main factors are the driving forces for MPB photosynthetic activity: temperature, inorganic carbon availability, and light (Admiraal 1984, Underwood \& Kromkamp 1999). Given the changes of several orders in magnitude observed over time, light is a major and complex driving force for MPB photosynthesis. In many intertidal estuaries, MPB must endure long periods of darkness, due to burial under layers of other algae or sediments, or because of the high attenuation of light by the water column during tidal immersion. In addition, MPB can be exposed to irradiances up to, or in excess of, $2000 \mu \mathrm{mol} \mathrm{m} \mathrm{m}^{-2} \mathrm{~s}^{-1}$ (with concomitant high UV-R), during daytime emersion, depending on season and the timing of tidal and nycthemeral rhythms (Perkins et al. 2001). Although such high irradiances are usually photoinhibitory in most algae (but this partly depends on algal light history), the question of MPB 
photoinhibition remains unanswered in situ. By analyzing variations in RLC (rETR/E) parameters from natural biofilms forming on sediments, and from engineered biofilms in which vertical migration was inhibited, our study partly answers the above question.

MPB with full migratory capacity maintained a high photosynthetic activity during the emersion period and showed no evidence of a decrease in photosynthetic activity or photodamage induced by UV-R or high PAR, which is in agreement with previous works (Blanchard \& Cariou-Le Gall 1994, Peletier et al. 1996, Kromkamp et al. 1998, Dodds et al. 1999, Underwood et al. 1999). However, when exposed to high irradiances, MPB unable to migrate (non-migratory engineered biofilms) showed a clear decrease in rETR compared to the migratory controls. This decrease in $\mathrm{rETR}_{\max }$ was enhanced by natural UV-B radiation. MPB is usually considered tolerant to ambient high PAR and UV-B (e.g. Peletier et al. 1996, Underwood et al. 1999, Roux et al. 2002), and migration thus appeared to be the principal short-term mechanism developed by MPB to cope with these photoinhibitory irradiances, in accordance with Waring et al. (2007). While continuous downward migration in response to high irradiance or UV-R seems to be a good photoprotective adaptation at the level of the single cell over the short term, it is not in fact a realistic strategy, devoid of ecological effects (decrease of primary productivity, but also of grazer pressure), for the microphytobenthic community as a whole, as outlined by Underwood et al. (1999) or Roux et al. (2002). Furthermore, shade-adapted cells can be observed at the sediment surface (Underwood et al. 2005), and MPB are potentially sensitive to enhanced levels of UV-B (Sundbäck et al. 1997, Waring et al. 2006). These observations have resulted in the hypothesis of vertical 'micro'-migration (e.g. Kromkamp et al. 1998, Consalvey et al. 2004), in which MPB moves upwards to sustain photosynthesis, and back into the mud or within the biofilm to minimize photoinhibitory effects of high irradiance, which has recently been demonstrated (Underwood et al. 2005, Waring et al. 2007). Due to low PAR and UV-R conditions, data collected at St Andrews cannot be used to support this hypothesis (no influence of a full migratory capacity), nor can they illustrate the respective effects of light components (PAR, UV-A, UV-B) on photosynthesis.

If in the short term 'micro'-migration seems a useful strategy to minimize photoinhibition resulting from high irradiances, in the longer term MPB can photoacclimate to various irradiances, as evidenced by the different shapes of the rETR/E curves. In experiments run in July and September 2003, rETR versus E curves were typical of high-light-acclimated algae, whereas in experiments run in April and June 2004, lightresponse curves were typical of low-light-acclimated algae, whether natural or induced.

Apart from seasonal changes (e.g. Serôdio \& Catarino 2000, Serôdio et al. 2006) and local differences in light conditions, species-specific differences in the biofilms could explain the differences in rETR versus $E$ curves (Underwood et al. 2005), although biomasses were composed of a few dominant and common genera or species. Light histories could also explain differences between high-light and low-light MPB biofilms, as for planktonic species (e.g. Anning et al. 2000, Quigg et al. 2003). Conditions were cloudy in St Andrews on the days before and during the experiments in April 2004, and on the days before sampling of the biofilm for the experiments carried out ex situ in Le Mans in June 2004. Furthermore, for these last experiments, MPB was artificially low-light acclimated for $3 \mathrm{~d}$, in order to change its photoacclimation status. It is unlikely that MPB was nutrient limited (seawater was changed each day), and at the beginning of the experiments, quantum yields higher than 0.4 were measured, reflecting rather healthy biomass, able to completely migrate into the sterilized mud in a few minutes ('migratory' treatment). MPB is thought to be well acclimated to high irradiances (e.g. Barranguet \& Kromkamp 2000), but recently it has been proposed to physiologically behave like cells photoacclimated to low light (Serôdio et al. 2005), although from changes in $E_{k}$ with time, MPB natural assemblages have been considered photoacclimated to high light (Serôdio et al. 2006). From our results, we cannot conclude whether MPB usually behaves like cells acclimated either to low or to high light, but this illustrates the importance of light history and the quantitative changes in irradiance experienced by the MPB over time.

In conclusion, the use of engineered biofilms with different migratory capacity evidences the importance of migration processes for MPB to cope with excessive irradiances, which in turn partly explains the ability of MPB to maintain high productivity in estuarine ecosystems. Typical 'light-shade' photoacclimation processes suggested by the shape of rETR versus $E$ curves probably superimpose on the behavioral (migratory) response to change in light environment, and thus to the short-term control for the maintenance of an optimal photosynthetic efficiency in MPB. Photoacclimation or down regulation, physiologically at the level of the photosynthetic apparatus, may therefore be regarded as the second mechanism of a 2 component strategy allowing MPB to respond to changes in light environment, and the balance between the 2 mechanisms could result from algal light history. Moreover, the use of UV filters with different cut-off wavelengths, by allowing estimation of the respective contribution of 
high PAR, UV-A, and UV-B to photoinhibition or photodamage, illustrates that UV-B is the most damaging component of light for photosynthesis, and confirms that MPB is rather tolerant to UV-R, as long as its migratory capacity is intact.

Acknowledgements. The comments of $\mathrm{H}$. MacIntyre and 2 anonymous reviewers greatly helped to improve this manuscript.

\section{LITERATURE CITED}

Admiraal W (1984) The ecology of estuarine sediment-inhabiting diatoms. Prog Phycol Res 3:271-318

Anning T, MacIntyre HL, Pratt SM, Sammes PJ, Gibb S, Geider JR (2000) Photoacclimation in the marine diatom Skeletonema costatum. Limnol Oceanogr 45:1807-1817

Barranguet C, Kromkamp J (2000) Estimating primary production rates from photosynthetic electron transport in estuarine microphytobenthos. Mar Ecol Prog Ser 204: $39-52$

Blanchard GF, Cariou-Le Gall V (1994) Photosynthetic characteristics of microphytobenthos in Marennes-Oléron Bay, France: preliminary results. J Exp Mar Biol Ecol 182:1-14

Blanchard GF, Guarini JM, Bacher C, Huet V (1998) Contrôle de la dynamique à court terme du microphytobenthos intertidal par le cycle exondation-submersion. CR Acad Sci Paris Sci Vie 321:501-508

Blanchard GF, Guarini JM, Orvain F, Sauriau PG (2001) Dynamic behaviour of benthic microalgal biomass in intertidal mudflats. J Exp Mar Biol Ecol 264:85-100

Blanchard GF, Guarini JM, Dang C, Richard P (2004) Characterizing and quantifying photoinhibition in intertidal microphytobenthos. J Phycol 40:692-696

Cohn SA, Disparti NC (1994) Environmental factors influencing diatom cell motility. J Phycol 30:818-828

Consalvey M, Paterson DM, Underwood GJC (2004) The ups and downs of life in a benthic biofilm: migration of benthic diatoms. Diatom Res 19:181-202

> Dodds WK, Biggs BJF, Lowe RL (1999) Photosynthesis-irradiance patterns in benthic microalgae: variations as a function of assemblage thickness and community structure. J Phycol 35:42-53

Eaton JW, Moss B (1966) The estimation of numbers and pigment content in epipelic algal populations. Limnol Oceanogr 11:584-595

Eilers PHC, Peeters JHC (1988) A model for the relationship between light intensity and the rate of photosynthesis in phytoplankton. Ecol Model 42:199-215

Franklin LA, Osmond CB, Larkum AWD (2003) Photoinhibition, UV-B and algal photosynthesis. In: Larkum AWD, Douglas SE, Raven JA (eds) Photosynthesis in algae. Kluwer Academic Publishers, Dordrecht, p 351-384

Genty B, Briantais JM, Baker NR (1989) The relationship between the quantum yield of photosynthetic electron transport and quenching of chlorophyll fluorescence. Biochim Biophys Acta 990:87-92

Herlory O, Richard P, Blanchard GF (2007) Methodology of light response curves: application of chlorophyll fluorescence to microphytobenthic biofilms. Mar Biol 153:91-101

Kromkamp J, Barranguet C, Peene J (1998) Determination of microphytobenthos PSII quantum efficiency and photosynthetic activity by means of variable chlorophyll fluorescence. Mar Ecol Prog Ser 162:45-55
Long SP, Humphries S, Falkowski PG (1994) Photoinhibition of photosynthesis in nature. Annu Rev Plant Physiol Plant Mol Biol 45:633-662

> MacIntyre HL, Geider RJ, Miller DC (1996) Microphytobenthos: the ecological role of the 'secret garden' of unvegetated, shallow-water marine habitats. 1. Distribution, abundance and primary production. Estuaries 19:186-201

> Morris EP, Forster RM, Peene J, Kromkamp JC (2008) Coupling between Photosystem II electron transport and carbon fixation in microphytobenthos. Aquat Microb Ecol 50:301-311

> Peletier H, Gieskes WW, Buma AGJ (1996) Ultraviolet-B radiation resistance of benthic diatoms isolated from tidal flats in the Dutch Wadden Sea. Mar Ecol Prog Ser 135:163-168

Perkins RG, Underwood GJC, Brotas V, Snow G, Jesus B, Ribeiro L (2001) Responses of microphytobenthos to light: primary production and carbohydrate allocation over an emersion period. Mar Ecol Prog Ser 223:101-112

Perkins RG, Oxborough K, Hanlon ARM, Underwood GJC, Baker NR (2002) Can chlorophyll fluorescence be used to estimate the rate of photosynthetic electron transport within microphytobenthic biofilms? Mar Ecol Prog Ser 228:47-58

> Perkins RG, Mouget JL, Lefebvre S, Lavaud J (2006) Light response curve methodology and possible implications in the application of chlorophyll fluorescence to benthic diatoms. Mar Biol 149:703-712

Press WH, Teukolsky SA, Vetterling WT, Flannery BP (2003) Numerical recipes in Fortran 77: the art of scientific computing, 2nd edn. Cambridge University Press, Cambridge

> Quigg A, Beardall J, Wydrzynski T (2003) Photoacclimation involves modulation of the photosynthetic oxygen-evolving reactions in Dunaliella tertiolecta and Phaeodactylum tricornutum. Funct Plant Biol 30:301-308

Ralph PJ, Gademann R (2005) Rapid light curves: a powerful tool to assess photosynthetic activity. Aquat Bot 82: $222-237$

Ratkowski DA (1983) Non linear regression modeling. A unified approach. Marcel Dekker, New York

Roux R, Gosselin M, Desrosiers G, Nozais C (2002) Effects of reduced UV radiation on a microbenthic community during a microcosm experiment. Mar Ecol Prog Ser 225:29-43

Schreiber U, Bilger W, Neubauer C (1994) Chlorophyll fluorescence as a non-intrusive indicator for rapid assessment of in vivo photosynthesis. Ecol Stud 100:49-70

> Serôdio J (2004) Analysis of variable chlorophyll fluorescence in microphytobenthos assemblages: implications of the use of depth-integrated measurements. Aquat Microb Ecol 36:137-152

Serôdio J, Catarino F (2000) Modelling the primary productivity of intertidal microphytobenthos: time scales of variability and effects of migratory rhythms. Mar Ecol Prog Ser 192:13-30

Serôdio J, Viera S, Cruz S, Barroso F (2005) Short-term variability in the photosynthetic activity of microphytobenthos as detected by measuring rapid light curves using variable fluorescence. Mar Biol 146:903-914

Serôdio J, Vieira S, Cruz S, Coelho H (2006) Rapid lightresponse curves of chlorophyll fluorescence in microalgae: relationship to steady-state light curves and nonphotochemical quenching in benthic diatom-dominated assemblages. Photosynth Res 90:29-43

Sundbäck K, Nilsson C, Odmark S, Wulff A (1996) Does ambient UV-B radiation influence marine diatom-dominated microbial mats? A case study. Aquat Microb Ecol 11: 151-159

Sundbäck K, Odmark S, Wulff A, Nilsson C, Wängberg SA 
(1997) Effects of enhanced UVB radiation on a marine benthic diatom mat. Mar Biol 128:171-179

Underwood GJC, Kromkamp J (1999) Primary production by phytoplankton and microphytobenthos in estuaries. Adv Ecol Res 29:93-153

Underwood GJC, Nilsson C, Sundbäck K, Wulff A (1999) Short-term effects of UV-B radiation on chlorophyll fluorescence, biomass, pigments, and carbohydrate fractions in a benthic diatom mat. J Phycol 35:656-666

Underwood GJC, Perkins RG, Consalvey M, Hanlon ARM, Oxborough K, Baker NR, Paterson DM (2005) Patterns in microphytobenthic primary productivity: species-specific variation in migratory rhythms and photosynthetic effi-

Editorial responsibility: Hugh MacIntyre,

Dauphin Island, Alabama, USA ciency in mixed-species biofilms. Limnol Oceanogr 50: 755-767

Waring J, Underwood GJC, Baker NR (2006) Impact of elevated UV-B radiation on photosynthetic electron transport, primary productivity and carbon allocation in estuarine epipelic diatoms. Plant Cell Environ 29:521-534

Waring J, Baker NR, Underwood GJC (2007) Response of estuarine intertidal microphytobenthic algal assemblages to enhanced ultraviolet B radiation. Glob Change Biol 13:1398-1413

Wulff A, Nilsson C, Sundbäck K, Wängberg SA, Odmark S (1999) UV radiation effects on microphytobenthos - a four month field experiment. Aquat Microb Ecol 19:269-278

Submitted: September 17, 2007; Accepted: June 3, 2008 Proofs received from author(s): August 27, 2008 